\title{
Dampak Urban Sprawl Terhadap Pola Pergerakan Studi Pada Koridor Jalan Letjend. Hertasning Kota Makassar
}

\author{
The Impact of Urban Sprawl on Study Movement Patterns in Letjend. \\ Hertasning Streets, Makassar city
}

\author{
Ariani Eka Syahfitri Arifin¹, Batara Surya², Agus Salim² \\ 1Dinas Pekerjaan umum dan Penataan Ruang Kota Parepare, Sulawesi Selatan \\ ${ }^{2}$ Program Studi Perencanaan Wilayah dan Kota, Program Pascasarjana, Universitas Bosowa \\ E-mail: arianiekasyahfitri13@gmail.com
}

Diterima: 20 Juli 2020/Disetujui 07 Desember 2020

\begin{abstract}
Abstrak. Penelitian ini bertujuan untuk mengidentifikasi ciri Urban sprawl yakni kenampakan kondisi hambatan samping, volume lalulintas, kompleksitas guna lahan, aktifitas ekonomi serta mengkaji dan menganalisis dampak urban sprawl terhadap pola pergerakan di Jalan Lenan Jend Hertasning Kota Makassar. Penelitian ini bersifat deskriptif kuantitatif dengan menggunakan alat analisis statistik deskriptif dengan menganalisis kenampakan guna lahan lokasi, metode Path Analisis dengan variabel Hambatan Samping, Volume Lalulintas, dan Kompleksitas Tata Guna Lahan dengan aplikasi SPSS. Data diperoleh dari Badan Pusat Statistik Kota Makassar dan masyarakat serta pengendara di Jalan Letjend Hertasning Kota Makassar yang bertindak sebagai responden. Hasil penelitian menunjukkan bahwa variabel Hambatan samping, Volume lalulintas, Kompleksitas Guna Lahan, Aktifitas Perdagangan Berpengaruh signifikan dan positif terhadap Pola Pergerakan secara simultan dengan penguatan pengaruh sebesar 97,8\%. Akifitas ekonomi mempengaruhi pola pergerakan jika ditinjau secara simultan dengan hambatan samping, volume lalulintas dan kompleksitas guna lahan. Adapun indikator yang paling mempengaruhi terhadap variabel Hambatan Samping pada ruas Jalan Letnan Jenderal Hertasning adalah kendaraan yang melambat sedangkan kendaraan masuk atau keluar merupakan kontribusi paling rendah. Kompleksitas guna lahan berbeda-beda di tiap segmen lokasi penelitian ruas Jalan Letnan Jenderal Hertasning dengan fungsi Permukiman, Perdagangan, Perkantoran, Sekolah, hingga Peribadatan dengan tingkat sederhana hingga kompleks. Adapun ketidak seimbangan jumlah pedagang formal dan nonformal yang didominasi oleh kegiatan perdagangan non formal pada Jl Letjend Hertasning arah ke Tun Abdul Razak. Berdasarkan hasil penelitian bahwa sebanyak 50\% responden memilih Jalan Letjen Hertasning sebagai tujuan atau asal untuk melakukan kegiatan ekonomi.
\end{abstract}

Kata Kunci: Pemekaran Kota, Pola Pergerakan, Transportasi, Makassar

\begin{abstract}
This research aims to identify the characteristics of Urban sprawl, which are the appearance of Side Friction conditions, Traffic Volume, Land Use Complexity, Economic Activity as well as to assess and analyse the effect of urban sprawl on Commuting Patterns in Letjend. Hertasning Street, Makassar City. This research is descriptive quantitative using descriptive statistical analysis tools by analyzing the appearance of the land use of the location, the Path Analysis method with the variables of Side Friction, Traffic Volume, and Land Use Complexity with the SPSS application. The data were obtained from the Makassar City Central Bureau of Statistics, and people and drivers passing through Letjend Hertasning Street, Makassar City, as respondents. The results showed that the variables of side friction, traffic volume, land use complexity, trading activity simultaneously have a significant and positive effect on commuting patterns of 97.8\%. Economic activity affects commuting patterns when assessed simultaneously with side frictions, traffic volume and land use complexity. The indicator that most influences the Side Friction variable on Letjend. Hertasning Street is the slowing down of vehicles, while the incoming or outgoing vehicle is the lowest contribution. The complexity of land use varies in each segment of the research location like Settlement Neighborhoods, Commerce, Offices, Schools, and Worship Places with simple to complex levels. There is an imbalance in the number of formal and non-formal traders dominated by non-formal trading activities in Letjend Hertasning Street in direction to Tun Abdul Razak Street. The results show that 50\% of respondents choose Letjend Hertasning Street as a place for economic activities.
\end{abstract}

Keywords: Urban Sprawl, Commuting Patterns, Transportation, Makkasar

\section{Pendahuluan}

Pertumbuhan perkotaan di Indonesia, terutama di kota-kota besar secara fisik ditandai oleh pertumbuhan yang pesat pada wilayah pinggiran perkotaan (urban fringe) yang dikenal sebagai proses suburbanisasi, yaitu pergeseran fungsi-fungsi kekotaan ke wilayah pinggiran perkotaan membentuk kawasan-kawasan permukiman baru. 
Suburbanisasi yang terjadi cenderung menjadikan kawasan perkotaan secara fisik meluas secara acak atau terpencar (urban sprawl) dan menjadi semakin tidak terkendali (Mahmud \& Achide, 2012).

Urbanisasi menurut Soetomo (2013) merupakan proses bergesernya masyarakat dari kehidupan perdesaan ke perkotaan. Secara tidak langsung, urbanisasi dapat mengakibatkan pertumbuhan kota, baik yang terkait jumlah penduduk maupun fisik kota (Karakayaci, 2017). Namun, tidak semua pertumbuhan kota sejalan dengan rancangan yang telah disusun. Pertumbuhan perkotaan seringkali terjadi di tengah-tengah wilayah perdesaan yang sebagian besar lahannya berupa lahan pertanian. Pertumbuhan kota yang tidak terencana ini dapat didefinisikan sebagai bentuk dari hasil urban sprawl (Sudhira \& Ramachandra, 2007). Semakin berkembangnya penduduk dan arus urbanisasi yang tinggi menyebabkan urban sprawl, yaitu proses perembetan kenampakan fisik kekotaan ke arah luar (Yunus, 2008).

Menurut Yunus (2008), selain disebabkan oleh peningkatan kebutuhan ruang, urban sprawl juga disebabkan karena adanya perubahan kemampuan sistem transportasi, pembangunan perumahan dan keberadaan infrastruktur. Munculnya kawasan-kawasan perumahan yang tersebar, tidak teratur dan tidak terintegrasi satu sama lain di daerah pinggiran memunculkan ruang-ruang kosong baik antarkawasan perumahan maupun antara kawasan perumahan dan pusat kota (Slaev, Aleksandar, \& Nikiforov, 2013). Hal tersebut menyebabkan tidak efisiennya penyediaan infrastruktur karena mahalnya biaya pengadaan yang tidak sebanding dengan jumlah penggunanya. Oleh karena itu, tidak salah apabila urban sprawl didefinisikan sebagai proses pertumbuhan wilayah pinggiran secara divergen dari inti kota, yaitu pertumbuhan kota yang tidak kompak sehingga menyebabkan sarana dan prasarana kota menjadi tidak efisien. Menurut Almeida (2005), karena tidak adanya sebuah definisi yang universal mengenai urban sprawl, maka pemetaan lahan terbangun merupakan awal yang tepat dalam mengkaji urban sprawl. Peta memberikan gambaran pertumbuhan perkotaan yang mengarah pada wilayah pinggiran kota. Perkembangan perkotaan dapat dipetakan dengan menggunakan data time series untuk membandingkan besarnya urban sprawl pada kurun waktu tertentu.

Perkembangan suatu wilayah, ditandai oleh perkembangan kota-kota sebagai nodal yang merupakan pusat konsentrasi penduduk dan segala aktivitas/kegiatan, senantiasa akan mengalami pertumbuhan dan berkembang baiksecara fisik, sosial, maupun ekonomi. Pengalokasian guna lahan di perkotaan akan mengarah ke lokasi yang dapat memberikan keuntungan tertinggi, sehingga lahanlahan yang memiliki tingkat kestrategisan dan potensi yang lebih besar akan lebih berpeluang mengalami proses perubahan pemanfaatan lahan. Pada umumnya gejala ini terjadi di jalan-jalan utama atau kawasan-kawasan tertentu yang memiliki keunikan dan karakteristik tersendiri (Yunus, 2008).

Perubahan pemanfaatan lahan non urban ke arah luar kota terutama oleh kegiatan manusia untuk bermukim dan aktivitas lainnya berlangsung secara bertahap seiring dengan waktu dan berkembangnya kota, proses perubahan sebagai peristiwa perembetan kenampakan fisik kota kearah luar tersebut terjadi karena adanya penetrasi dari suatu kelompok penduduk area terbangun kota (built up area) kearah luar. Gejala adanya perembetan kota dapat terlihat dari kenampakan fisik kota ke arah luar yang ditunjukan oleh terbentuknya zone-zone meliputi daerahdaerah: pertama, area yang melingkari sub urban dan merupakan daerah peralihan antara desa kota (suburban fringe), kedua area batas luar kota yang mempunyai sifatsifat mirip kota (urban fringe), dan ketiga adalah area terletak antara daerah kota dan desa yang ditandai dengan penggunaan tanah campuran (Bintarto, 1983).

Kota metropolitan yang berkembang di Indonesia kian memperluas jaringan pelayanannya. Dalam suatu area yang kemudian disebut sebagai pusat kota pada suatu distrik atau daerah kini menjadi 'kota inti' yang kemudian melahirkan hinterland atau daerah penunjang disekitarnya yang menyebabkan perluasan pelayanan kota. Akibatnya kebutuhan ruang yang semakin meningkat di daerah perkotaan tersebut mendorong terjadinya perkembangan daerah di kawasan suburban yang dikenal dengan gejala invansion. Fenomena perkembangan daerah secara acak mulai meluas. Selain pemekaran kota (urban sprawl) membuat lahan produktif semakin berkurang, menyebabkan pula perubahan bentuk kota atau morfologi kota yang tidak teratur.

Saat ini kondisi Kota Makassar sudah mengalami ciri dimana pusat kegiatan sudah tidak fokus pada tengah kota melainkan telah berkembang dan memiliki sub-bagian atau yang sering disebut Multiple nuclei. Selain dikarenakan posisi penting Makassar dalam wilayah Mamminasata sebagai core, pengembangan wilayah inipun didukung oleh daerah yang berbatasan langsung dengan Kota Makassar dapat menopang perkembangan ibukota provinsi Sulawesi Selatan.

Semakin kompleksnya guna fungsi lahan pada suatu koridor jalan maka memunculkan potensi-potensi sektor perdagangan yang berkembang sepanjang koridor jalan tersebut. Hal tersebut yang kemudian akan diteliti pengaruhnya terhadap pergerakan lalu lintas kendaraan. Mengingat keberadaan perdagangan sektor formal dan non formal merupakan salah satu jenis hambatan samping yang muncul akibat adanya pemekaran kota ke arah pinggiran. Adapun ciri fenomena Urban Sprawl yang Nampak adalah peningkatan hambatan samping dan volume lalu lintas, kompleksitas guna lahan, perdagangan formal dan non formal yang semakin kompleks serta ciri pola pergerakan sepanjang koridor jalan tersebut. Pengembangan kawasan perumahan terhadap sosial ekonomi masyarakat telah mempengaruhi mata pencaharian dan penghasilan penduduk menjadi lebih baik. Jenis dan skala usaha mengalami peningkatan diakibatkan tingginya permintaan penunjang kehidupan masyarakat perumahan yang bersifat lebih konsumtif (Nasaruddin dkk, 2020).

Perkembangan dan pertumbuhan Kota Makassar dalam kedudukannya sebagai kota inti dalam wilayah Metropolitan Mamminasata, ditandai dengan proses urbanisasi dan migrasi desa-kota yang berlangsung sangat insentif dan menempati beberapa lokasi kawasan pinggiran. Jalan hertasning ini merupakan salah satu rencana pembangunan jalan akses CPOI (Center Pont Of Indonesia) ke kabupaten Gowa dan Maros. Peran koridor utama dalam wilayah Makassar secara khusus dan Mamminasata secara umum memicu pola penyebaran konsentrasi aktifitas di wilayah pinggiran. Ditunjang oleh posisi Jalan Letjend 
Hertasning yang juga merupakan koridor penghubung kabupaten yang berbatasan langsung yakni Kab Gowa dan lingkar tengah Makassar Jl. A.P Pettarani. Adapun penelitian Sakti (2016) mengenai fenomena urban sprawl di koridor Hertasning - Samata melahirkan kesimpulan bahwa pertumbuhan aktifitas perkotaan berkontribusi secara positif terhadap perdagangan, permukiman, pendidikan serta jaringan pergerakan

\section{Metode Penelitian}

a. Jenis Penelitian

Jenis penelitian yang digunakan dalam penelitian ini adalah dekriptif kuantitatif dimana penelitian ini bertujuan untuk mendeskripsikan realitas yang ada di suatu masyarakat dengan angka-angka dan analisis menggunakan statistik. Penelitian deskriptif memungkinkan peneliti untuk melakukan hubungan antar variabel, menguji hipotesis, mengembangkan generalisasi, dan mengembangkan teori yang memiliki validitas universal. Sementara penelitian ini merupakan penelitian kuantitatif karena penelitian ini banyak dituntut menggunakan angka, mulai dari pengumpulan data, penafsiran terhadap data, serta penampilan datanya dengan menggunakan Analisis kinerja jalan dan Analis Path .

\section{b. Lokasi Penelitian}

Penelitian ini dilakukan di Ruas Jalan Letnan Jendral Hertasning, Kecamatan Rappocini, Kota Makassar Provinsi Sulawesi Selatan. Koridor jalan tersebut merupakan jalan utama penghubung daerah pusat Kota Makassar ke area sub urban (pinggiran) Kota Makassar serta menghubungkan Kota Makassar menuju Kabupaten Gowa. Adapun sepanjang koridor tersebut sudah nampak perubahan dan bercirikan fenomena urban sprawl kota Makassar yang menjadi representatif perkembangan kota.

\section{c. Teknik Analisis}

Untuk menjawab rumusan masalah dalam penelitian ini digunakan alat analisis terkait fenomena Urban Sprawl dan kondisi lokasi penelitian. Adapun alat analisis dalam penelitian ini sebagai berikut:

1. Rumusan masalah pertama dalam penelitian ini yaitu bagaimana ciri urban sprawl yang nampak di sepanjang koridor Jalan Let.Jend Hertasning, Kota Makassar. Sehingga alat analisis dalam penelitian ini yaitu menggunakan analisis statistik deskriptif dengan menganalisis kenampakan guna lahan lokasi. Variabel Penelitian :

X1 : Hambatan Samping

Tabel 1. Variabel Hambatan Samping

\begin{tabular}{|c|c|c|c|}
\hline No & $\begin{array}{c}\text { Variabel } \\
\text { Penelitian } \\
\end{array}$ & Indikator & Metode \\
\hline \multirow[t]{6}{*}{1} & Hambatan & Pejalan kaki, & \multirow{2}{*}{$\begin{array}{l}\text { Observasi } \\
\text { Perhitungan }\end{array}$} \\
\hline & \multirow[t]{5}{*}{ Samping } & $\begin{array}{ll}\text { Angkutan } \quad \text { umum } \\
\end{array}$ & \\
\hline & & $\begin{array}{l}\text { Kendaraan lain yang berhenti } \\
\text { (parkir), }\end{array}$ & \multirow{4}{*}{$\begin{array}{l}\text { sesuai Manual } \\
\text { Kapasitas Jalan } \\
1997 \quad \text { (Sangat } \\
\text { Berpengaruh - } \\
\text { Tidak } \\
\text { Berpengaruh) }\end{array}$} \\
\hline & & Kendaraan masuk dan keluar & \\
\hline & & dari lahan di samping jalan, & \\
\hline & & Kendaraan yang melambat & \\
\hline
\end{tabular}

Faktor Penyesuaian Kapasitas Untuk Hambatan Samping (FCSF) didasarkan atas lebar bahu efektif WS dari kelas hambatan samping (SFC) .

X2: Volume Lalulintas

Tabel 2. Variabel Volume Lalulintas

\begin{tabular}{llllr}
\hline No & $\begin{array}{c}\text { Variabel } \\
\text { Penelitian }\end{array}$ & \multicolumn{2}{c}{ Indikator } & \multicolumn{2}{c}{ Metode } \\
\hline 2 & Volume & Arus Lalu Lintas & $\begin{array}{l}\text { Observasi } \\
\text { Perhitungan }\end{array}$ & $\begin{array}{r}\text { dan } \\
\text { sesuai } \\
\text { Lalu Lintas }\end{array}$ \\
\cline { 3 - 5 } & Equivalen Mobil & $\begin{array}{l}\text { Manual Kapasitas Jalan } \\
\text { Eenumpang (emp) }\end{array}$ & $\begin{array}{l}\text { 1997 (Sangat tinggi / } \\
\text { padat - rendah) }\end{array}$ \\
\hline
\end{tabular}

Menetapkan kondisi lalu lintas berdasarkan hasil survei perhitungan lalu lintas. Arus lalu lintas (Q) dihitung langsung dengan survei perhitungan volume lalu lintas (kendaraan per jam) untuk kendaraan ringan, kendaraan berat dan sepeda motor. Semua nilai arus lalu lintas (per arah dan total) diubah menjadi satuan mobil penumpang (smp) dengan menggunakan ekuivalensi mobil penumpang (emp), untuk masing-masing tipe kendaraan tergantung pada tipe jalan arus lalu lintas total yang dinyatakan dalam kendaraan/jam.

Varabel ini diselesaikan dengan metode Analisis Kinerja Jalan.

a. Langkah pertama

Menjelaskan secara umum gambaran data pada ruas jalan seperti jumlah penduduk, guna lahan, panjang jalan dan geometrik jalan.

b. Langkah kedua

Menetapkan kondisi lalu lintas berdasarkan hasil survei perhitungan lalu lintas. Arus lalu lintas (Q) dihitung langsung dengan survei perhitungan volume lalu lintas (kendaraan per jam) untuk kendaraan ringan, kendaraan berat dan sepeda motor. Semua nilai arus lalu lintas (per arah dan total) diubah menjadi satuan mobil penumpang (smp) dengan menggunakan ekvalensi mobil penumpang (emp), untuk masing-masing tipe kendaraan tergantung pada tipe jalan arus lalu lintas total yang dinyatakan dalam kendaraan/jam.

c. Langkah ketiga

Menganalisis kapasitas yang dilakukan dengan menggunakan rumus persamaan (MKJI, 1997;5-18) sebagai berikut :

$\mathrm{C}=\mathrm{CO} \times \mathrm{FCW} \times \mathrm{FCSP} \times \mathrm{FCSF} \times \mathrm{FCCS}$

dimana:

$\mathrm{C}=\operatorname{Kapasitas}(\mathrm{smp} / \mathrm{jam})$

$\mathrm{CO}=$ Kapasitas dasar $(\mathrm{smp} / \mathrm{jam})$

$\mathrm{FCW}=$ Faktor penyesuaian lebar jalan

FCSP $=$ Faktor penyesuaian pemisahan arah (hanya untuk jalan tak terbagi)

$\mathrm{FCSF}=$ Faktor penyesuaian hambatan samping dan bahu jalan/kereb

FCCS $=$ Faktor penyesuaian ukuran kota (jumlah penduduk)

d. Langkah kempat

Menentukan Volume Capasitas Ratio (VCR) atau Derajat Kejenuhan dengan rumus persamaan sebagai berikut :

$\operatorname{VCR}(\mathrm{DS})=\mathrm{Q} / \mathrm{C}$

dimana :

VCR = Volume Capasitas Ratio 
DS = Derajat Kejenuhan

$\mathrm{Q}=$ Arus lalu lintas (smp/jam)

$\mathrm{C}=\operatorname{Kapasitas}(\mathrm{smp} / \mathrm{jam})$

X3: Kompleksitas Tata Guna Lahan

Tabel 3 Variabel Kompleksitas Tata Guna Lahan

\begin{tabular}{ccccc}
\hline No & $\begin{array}{c}\text { Variabel } \\
\text { Penelitian }\end{array}$ & \multicolumn{2}{c}{ Indikator } & \multicolumn{2}{c}{ Metode } \\
\hline 3 & Kompleksitas & Jumlah Tata Guna & Observasi & (Sangat \\
& Guna Lahan & Lahan & & Kompleks \\
& & & Sederhana) & - \\
\hline
\end{tabular}

Penggunaan Lahan seperti Perumahan, Perdagangan, Pendidikan dan sebagainya.

Y: Aktifitas Koridor (Kegiatan Ekonomi Formal / Non Formal

Tabel 4 Variabel Aktifitas Koridor

\begin{tabular}{|c|c|c|c|}
\hline No & $\begin{array}{c}\text { Variabel } \\
\text { Penelitian }\end{array}$ & Indikator & Metode \\
\hline \multirow[t]{6}{*}{4} & \multirow[t]{3}{*}{ Kegiatan Formal } & Aktifitas & \multirow{6}{*}{$\begin{array}{l}\text { Observasi } \\
\text { Kuisioner }\end{array}$} \\
\hline & & $\begin{array}{ll}\text { Jenis } & \text { Pedagang } \\
\text { Formal } & \end{array}$ & \\
\hline & & $\begin{array}{l}\text { Moda Pedagang } \\
\text { Formal }\end{array}$ & \\
\hline & \multirow{3}{*}{$\begin{array}{l}\text { Kegiatan } \\
\text { Formal }\end{array}$} & Aktifitas & \\
\hline & & $\begin{array}{l}\text { Jenis Pedagang } \\
\text { Non Formal }\end{array}$ & \\
\hline & & $\begin{array}{l}\text { Moda Pedagang } \\
\text { Non Formal }\end{array}$ & \\
\hline
\end{tabular}

Z: Pola Pergerakan

Tabel 4 Variabel Pola Pergerakan

\begin{tabular}{clll}
\hline No & \multicolumn{1}{c}{$\begin{array}{c}\text { Variabel } \\
\text { Penelitian }\end{array}$} & \multicolumn{1}{c}{ Indikator } & \multicolumn{2}{c}{ Metode } \\
\hline 5 & Pola & Asal (Origin) & Kuisioner dan \\
& Pergerakan & $\begin{array}{l}\text { Tujuan (Destination) } \\
\text { Tujuan Kervasi } \\
\end{array}$ & Pegiatan \\
& & & \\
\hline
\end{tabular}

2. Rumusan masalah kedua dalam penelitian ini yakni adakah pengaruh aktifitas guna lahan terhadap pola pergerakan sepanjang koridor Jalan Let. Jend Hertasning Kota Makassar, menggunakan metode Path Analisis dengan variabel Hambatan Samping, Volume Lalulintas, dan Kompleksitas Tata Guna Lahan dengan aplikasi SPSS. Analisis jalur atau path analysis merupakan salah satu metode analisis regresi yang lebih lanjut dimana menguji pengaruh variabel intervening (Z) dimana penggunaan analisis regresi untuk menaksir hubungan kausalitas antar variabel. Analisis ini digunakan untuk mengatahui pengaruh langsung dan tidak langsung.

\section{Hasil dan Pembahasan}

Hasil dan pembahasan dalam penelitian ini menguraikan tentang dampak urban sprawl terhadap pola pergerakan pada koridor jalan di Kota Makassar yakni sebagai berikut. Pembahasan tersebut dijabarkan sebagai berikut:

1. Karakteristik Lokasi Penelitian Dibedakan Berdasarkan

Jalur Dan Waktu Penelitian, Berdasarkan Aktifitas

Kegiatan Ekonomi, Dan Berdasarkan Responden Pengguna Jalan.

Analisis Deskriptif dilakukan untuk menggambarkan keadaan masing-masing variabel sesuai dengan indikatornya dengan menggunakan skala likert . adapun variabel -variabel dalam penelitian ini adalah sebagai berikut:

(1) Hambatan Samping

Berdasarkan Tabel 5 dan tabel 6 menunjukkan bahwa kendaraan yang melambat berkontribusi paling tinggi sedangkan kendaraan masuk atau keluar merupakan kontribusi paling rendah terhadap variabel hambatan samping.

(2) Volume Lalu Lintas

Volume lalu lintas adalah banyaknya kendaraan yang melewati suatu titik atau garis tertentu pada suatu penampang melintang jalan. Volume lalulintas terbagi menjadi 4 segmen sesuai dengan yang dipaparkan pada tinjauan lokasi penelitian. Berikut adalah hasil rekapitulasi volume lalu lintas sepanjang koridor jalan Letjend. Hertasing sesuai dengan analisis kapasitas jalan dapat dilihat pada Tabel 7 dan Tabel 8.

Berdasarkan tabel 8 disimpulkan bahwa Segmen IV pada ruas Jl. Letjend Hertasning berkontribusi sangat tinggi terhadap volume lalu lintas sebesar 50,93\% dan paling rendah adalah Segmen IB senilai 3,72\%.

(3) Kompleksitas Guna Lahan

Pada lokasi penelitian Jalan Letjend. Hertasning, Kota Makassar, terdapat berbagai macam fungsi guna lahan yang berbeda-beda sepanjang koridor. Hal ini menyebabkan berkembangnya tata guna lahan disekitar yang semakin kompleks. Bervariasinya guna lahan dalam suatu kawasan merupakan bukti kompleksitas dalam aktifitas sepanjang koridor. Data kompleksitas guna lahan dapat dilihat pada Tabel 9 dan Tabel 10.

Berdasarkan Tabel 10 disimpulkan bahwa kompleksitas guna lahan pada 4 segmen yang diuji dalam perbedaan 3 waktu observasi berkontribusi masing-masing 25\% pada kelas Sangat Kompleks, Kompleks, Kurang Kompleks, dan Cukup Kompleks.

(4) Aktivitas Perdagangan

Aktifitas perdagangan pada lokasi ini terbagi menjadi 2 yakni Formal dan Non Formal dan dibagi dalam 5 kelas berdasarkan jumlah aktifitas perdagangan dapat dilihat pada Tabel 11 dan Tabel 12.

(5) Pola Pergerakan

Jalan Letjend. Hertasning merupakan salah satu jalan penghubung antara Gowa dan Maros dari Makassar. Pada observasi dan penghimpunan hasil data kuisioner yang peneliti lakukan didapatkan terlihat pola pergerakan dominan yakni :

- Jalan Letjend. Hertasning sebagai jalur utama untuk bekerja.

- Jalan Letjend. Hertasning sebagai Tujuan atau asal perjalanan untuk melakukan kegiatan kerja

- Jalan Letjend Hertasning sebagai Tujuan atau asal untuk melakukan kegiatan ekonomi.

Tabel 13 Distribusi Frekuensi Variabel Pola Pergerakan

\begin{tabular}{lcccccccc}
\hline \multirow{2}{*}{ Item } & \multicolumn{2}{c}{1} & \multicolumn{2}{c}{2} & \multicolumn{2}{c}{3} & \multicolumn{2}{c}{ Total } \\
\cline { 2 - 8 } & $\mathrm{F}$ & $\%$ & $\mathrm{~F}$ & $\%$ & $\mathrm{~F}$ & $\%$ & $\mathrm{~F}$ & $\%$ \\
\hline Pola & 3 & $25 \%$ & 3 & $25 \%$ & 6 & $50 \%$ & 12 & 100 \\
Pergerakan & & & & & & & & \\
\hline Sumber: Hasil Analisis, 2020 & & & & & &
\end{tabular}

Berdasarkan Tabel 13 disimpulkan bahwa pola pergerakan dominan pada 4 segmen yang diuji dalam 3 perbedaan waktu adalah Jalan Letjen Hertasning sebagai tujuan atau asal untuk melakukan kegiatan ekonomi sebesar 50\%

2. Uji Analisis Jalur 
Analisis jalur atau path analysis merupakan salah satu metode analisis regresi yang lebih lanjut dimana menguji pengaruh variabel intervening $(Z)$ dimana penggunaan analisis regresi untuk menaksir hubungan kausalitas antar variabel. Analisis ini digunakan untuk mengatahui pengaruh langsung dan tidak langsung. Pada penelitian ini membagi 2 persamaan Adapun model regresi sebagai berikut:

(1) Kooerfisien Jalur Model I

Mengacu pada output Regresi model I pada bagian tabel Coefficients dapat diketahui bahwa nilai signifikansi dari variabel $\mathrm{X} 1=0,011, \mathrm{X} 2=0,033$, dan X3 = 0,000 lebih kecil dari 0,05 artinya variabel Hambatan Samping, Volume Lalulintas, dan Kompleksitas Guna Lahan berpengaruh secara signifikan terhadap Aktifitas Ekonomi (Y).

Tabel 14 Hasil Uji Model I

\begin{tabular}{|c|c|c|c|c|c|c|}
\hline & \multirow{3}{*}{ Model } & \multirow{2}{*}{\multicolumn{2}{|c|}{$\begin{array}{c}\text { Coefficients } \\
\text { Unstandardized } \\
\text { Coefficients } \\
\end{array}$}} & \multirow{3}{*}{$\frac{\begin{array}{c}\text { Stand. } \\
\text { Coefficie }\end{array}}{\text { Beta }}$} & \multirow{3}{*}{$\mathrm{t}$} & \multirow{3}{*}{ Sig. } \\
\hline & & & & & & \\
\hline & & B & \multirow{2}{*}{$\begin{array}{c}\begin{array}{c}\text { Std. } \\
\text { Error }\end{array} \\
2,168\end{array}$} & & & \\
\hline 1 & (Constant) & 13,487 & & & 6,220 &, 000 \\
\hline & Hambatan Samping & ,159 & ,049 & 3,208 & 3,270 & ,011 \\
\hline & Volume Lalulintas &,- 022 & ,009 & $-2,508$ & $-2,567$ &, 033 \\
\hline & Tata Guna Lahan & $-2,561$ &, 345 &,- 400 & $-7,425$ &, 000 \\
\hline
\end{tabular}

Tabel 15 Hasil Uji Koefisien Determinan Model I

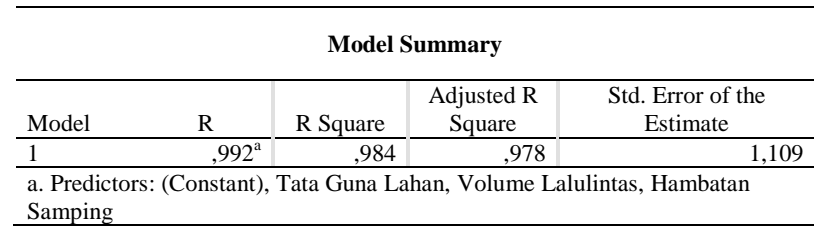

Besarnya nilai adjusted R Square yang terdapat pada tabel di atas adalah sebesar 0,978, hal ini menunjukkan bahwa kontribusi pengaruh $\mathrm{X} 1, \mathrm{X} 2$ dan X3 terhadap Y adalah sebesar 97,8\% sementara 2,2\% merupakan kontribusi variabel-variabel lain yang tidak dimasukkan dalam penelitian. Sementara itu, untuk nilai $\varepsilon 1$ dapat diperoleh dari rumus $\varepsilon 1=\sqrt{ }(1-0,978)=$ 0,148 .

\section{(2) Koefisien Jalur Model II}

Mengacu pada output Regresi model II pada bagian tabel Coefficients dapat diketahui bahwa nilai signifikansi dari variabel $\mathrm{X} 1=0,787$ dan $\mathrm{X} 2=0,579$ dimana lebih besar dari 0,05 sedangkan $\mathrm{X} 3=0,008$, dan $\mathrm{Y}=0,032$ lebih kecil dari 0,05 . Hasil ini memberikan kesimpulan bahwa regresi model II, yakni variabel Hambatan Samping dan Volume Lalulintas berpengaruh tidak signifikan sedangkan Kompleksitas Guna Lahan dan Aktifitas Ekonomi berpengaruh signifikan terhadap Pola Pergerakan.

Tabel 16 Hasil Uji Model II

\begin{tabular}{|c|c|c|c|c|c|c|}
\hline \multicolumn{7}{|c|}{ Coefficients $^{\mathrm{a}}$} \\
\hline & \multirow[t]{2}{*}{ Model } & \multicolumn{2}{|c|}{$\begin{array}{l}\text { Unstandardized } \\
\text { Coefficients }\end{array}$} & \multirow{2}{*}{$\begin{array}{c}\text { Standardi } \\
\text { Coeffici } \\
\text { Beta }\end{array}$} & \multirow[t]{2}{*}{$\mathrm{t}$} & \multirow[t]{2}{*}{ Sig. } \\
\hline & & $\mathrm{B}$ & Std. Error & & & \\
\hline \multirow[t]{5}{*}{1} & (Constant) & 4,188 &, 898 & & 4,665 & ,002 \\
\hline & Hambatan Samping & ,004 & 013 & ,622 & ,280 & ,787 \\
\hline & Volume Lalulintas & ,001 & 002 & 1,134 & ,581 & ,579 \\
\hline & Tata Guna Lahan &,- 613 & , 166 &,- 826 & $-3,690$ & ,008 \\
\hline & Aktifitas Ekonomi &,- 162 & 061 & $-1,394$ & $-2,666$ &, 032 \\
\hline
\end{tabular}

Tabel 17 Hasil Uji Koefisien Determinan Model II

\begin{tabular}{|c|c|c|c|c|}
\hline \multicolumn{5}{|c|}{ Model Summary } \\
\hline Model & $\mathrm{R}$ & R Square & $\begin{array}{l}\text { Adjusted R } \\
\text { Square }\end{array}$ & $\begin{array}{l}\text { Std. Error of the } \\
\text { Estimate }\end{array}$ \\
\hline 1 &, $985^{\mathrm{a}}$ & 969 & ,952 & ,190 \\
\hline
\end{tabular}

Besarnya nilai adjusted R Square yang terdapat pada tabel II di atas adalah sebesar 0,952, hal ini menunjukkan bahwa kontribusi pengaruh $\mathrm{X} 1, \mathrm{X} 2, \mathrm{X} 3$ dan $\mathrm{Y}$ terhadap $\mathrm{Z}$ adalah sebesar 95,2\% sementara 4,8\% merupakan kontribusi variabel-variabel lain yang tidak dimasukkan dalam penelitian. Sementara itu, untuk nilai $\varepsilon 2$ dapat diperoleh dari rumus $\varepsilon 2=\sqrt{ }(1-0,952)=$ 0,219 .

\section{- Uji Hipotesis}

Untuk menguji dugaan sementara atau hipotesis pada penelitian ini dilakukan Uji $\mathrm{F}$ dan $\mathrm{Uji} \mathrm{T}$ untuk mengetahui pengaruh variabel $\mathrm{X}$ secara stimultan sedangkan uji T berguna untuk mengetahui pengaruh secara parsial atau sebagian terhadap variabel $\mathrm{Y}$ dan $\mathrm{Z}$ dengan menggunakan dua model regresi seperti sebelumnya. berikut:

Adapun hipotesis penelitian Model 1 adalah sebagai

(a) Variabel hambatan samping (X1) berpengaruh signifikan dan berhubungan positif terhadap Aktifitas ekonomi (Y).

(b) Variabel volume lalulintas (X2) berpengaruh signifikan dan berhubungan positif terhadap Aktifitas ekonomi (Y)

(c) Variabel kompleksitas guna lahan (X3) berpengaruh signifikan dan berhubungan positif terhadap Aktifitas ekonomi (Y)

(d) Variabel hambatan samping (X1), volume lalulintas (X2) kompleksitas guna lahan (X3) berpengaruh signifikan dan berhubungan positif terhadap Aktifitas ekonomi (Y).

Adapun hipotesis penelitian Model 2 adalah sebagai berikut:

(a) Variabel hambatan samping (X1), volume lalulintas (X2) kompleksitas guna lahan (X3) dan Aktifitas ekonomi (Y) berpengaruh secara simultan serhadap Pola Pergerakan (Z).

(b) Variabel hambatan samping (X1), volume lalulintas (X2) kompleksitas guna lahan (X3) dan Aktifitas ekonomi (Y) berpengaruh secara parsial terhadap Pola Pergerakan $(\mathrm{Z})$.

1. Uji Hipotesis Model I

Tabel 18 Hasil Uji Hipotesis Simultan (Uji-F) Model I

\begin{tabular}{|c|c|c|c|c|c|c|}
\hline \multicolumn{7}{|c|}{ ANOVA $^{\mathrm{a}}$} \\
\hline & Model & $\begin{array}{c}\text { Sum of } \\
\text { Squares }\end{array}$ & df & $\begin{array}{c}\text { Mean } \\
\text { Square }\end{array}$ & $\mathbf{F}$ & Sig. \\
\hline \multirow[t]{3}{*}{1} & Regression & 604,419 & 3 & 201,473 & 163,956 &, $000^{\mathrm{b}}$ \\
\hline & Residual & 9,831 & 8 & 1,229 & & \\
\hline & Total & 614,250 & 11 & & & \\
\hline
\end{tabular}

Berdasarkan Tabel 8 di atas dapat diketahui bahwa nilai probabilitas signifikan sebesar 0,000. Karena nilai sig. $0,000<0,05$, maka sesuai dengan dasar pengambilan keputusan dalam uji $\mathrm{F}$ dapat disimpulkan bahwa Hambatan Samping (X1), Volume Lalulintas (X2), dan Kompleksitas guna lahan secara bersama-sama mempengaruhi Aktifitas ekonomi (Y) di sepanjang koridor Jalan Letjend. Hertasning . Perbandingan nilai $\mathrm{F}$ hitung dengan $\mathrm{F}$ tabel dimana nilai $F$ sebesar 163,956, dimana variabel bebas dinyatakan berpengaruh secara simultan apabila $\mathrm{F}$ hitung > $F$ tabel dan nilai signifikan $<0,05$. Nilai $F$ tabel dapat dihitung dengan rumus $\mathrm{F}=(\mathrm{k} ; \mathrm{n}-\mathrm{k})=\mathrm{F}(3 ; 9)=3$,86. Jadi dapat disimpulkan bahwa nilai sig. $0,00<0,05$ dan $\mathrm{F}$ hitung > F tabel maka Hipotesis ke 4 diterima yakni Variabel hambatan samping (X1), volume lalulintas (X2) kompleksitas guna lahan (X3) berpengaruh secara simultan terhadap Aktifitas ekonomi (Y). 
Tabel 19 Hasil Uji Hipotesis Simultan (Uji-T) Model I

\begin{tabular}{|c|c|c|c|c|c|c|}
\hline \multicolumn{7}{|c|}{ Coefficients $^{\mathrm{a}}$} \\
\hline & \multirow[t]{2}{*}{ Model } & \multicolumn{2}{|c|}{$\begin{array}{l}\text { Unstandardized } \\
\text { Coefficients }\end{array}$} & \multirow{2}{*}{$\begin{array}{c}\text { Standard. } \\
\text { Coefficients } \\
\text { Beta }\end{array}$} & \multirow[t]{2}{*}{$\mathbf{t}$} & \multirow[t]{2}{*}{ Sig. } \\
\hline & & B & Std. Error & & & \\
\hline \multirow[t]{4}{*}{1} & (Constant) & 13,487 & 2,168 & & 6,220 & ,000 \\
\hline & Hambatan Samping & ,159 & 049 & 3,208 & 3,270 & 011 \\
\hline & Volume Lalulintas &,- 022 & 009 & $-2,508$ & $-2,567$ & 033 \\
\hline & Tata Guna Lahan & $-2,561$ &, 345 &,- 400 & $-7,425$ &, 000 \\
\hline
\end{tabular}

a. Dependent Variable: Aktifitas Ekonomi

Berdasarkan tabel 19 jika nilai sig $<0,05$ atau $\mathrm{T}$ hitung > $\mathrm{T}$ tabel maka terdapat pengaruh variabel $\mathrm{X}$ terhadap variabel $\mathrm{Y}$. Variabel $\mathrm{X} 1=0,011, \mathrm{X} 2=0,033$, dan $\mathrm{X} 3=0,000$ lebih kecil dari 0,05 artinya variabel Hambatan Samping, Volume Lalulintas, dan Kompleksitas Guna Lahan berpengaruh secara signifikan terhadap Aktifitas Ekonomi (Y).

Nilai $\mathrm{T}$ tabel dapat dihitung dengan $\mathrm{df}=(\mathrm{n}-\mathrm{k}-1)=$ 2,306. Nilai $\mathrm{T}$ hitung $\mathrm{X} 1=3,270>\mathrm{T}$ tabel maka terdapat pengaruh positif variabel $\mathrm{X} 1$ terhadap $\mathrm{Y}$ sedangkan Nilai $\mathrm{T}$ hitung $\mathrm{X} 2=-2,567$ dan $\mathrm{X} 3=-7,425<\mathrm{T}$ tabel 2,306 maka tidak terdapat pengaruh $\mathrm{X} 2$ dan $\mathrm{X} 3$ terhadap $\mathrm{Y}$ secara parsial.

\section{Uji Hipotesis Model II}

Tabel 20 Hasil Uji Hipotesis Simultan (Uji-F) Model II

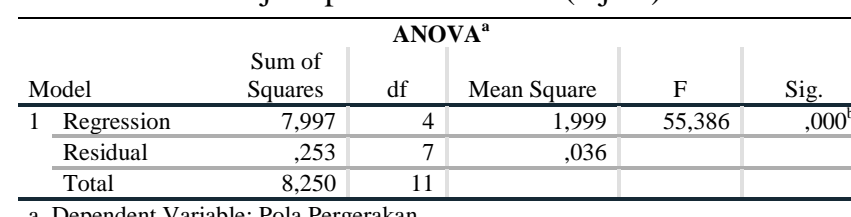

Dependent Variable: Pola Pergerakan

b. Predictors: (Constant), Aktifitas Ekonomi, Tata Guna Lahan, Volume Lalulintas, Hambatan Samping

Berdasarkan tabel 4.59 di atas dapat diketahui bahwa nilai probabilitas signifikan sebesar 0,000. Karena nilai sig. $0,000<0,05$, maka sesuai dengan dasar pengambilan keputusan dalam uji F dapat disimpulkan bahwa Hambatan Samping (X1), Volume Lalulintas (X2), Kompleksitas guna lahan (X3), dan Aktifitas ekonomi (Y) secara bersamasama mempengaruhi Pola pergerakan (Z) di sepanjang koridor Jalan Letjend. Hertasning .

Perbandingan nilai $\mathrm{F}$ hitung dengan $\mathrm{F}$ tabel dimana nilai $F$ sebesar 55,386. dinyatakan berpengaruh secara simultan apabila $\mathrm{F}$ hitung > F tabel dan nilai signifikan < 0,05 , nilai $F$ tabel dapat dihitung dengan rumus $F=(k ; n-k)$ $=\mathrm{F}(3 ; 9)=3,86$. Jadi dapat disimpulkan bahwa nilai sig. $0,000<0,05$ dan $\mathrm{F}$ hitung $>\mathrm{F}$ tabel maka Hipotesis dapat diterima yakni Variabel hambatan samping (X1), volume lalulintas (X2) kompleksitas guna lahan (X3) dan Aktifitas ekonomi (Y) berpengaruh secara simultan serhadap Pola Pergerakan (Z).

Tabel 21 Hasil Uji Hipotesis Simultan (Uji-T) Model II

\begin{tabular}{l|r|r|r|r|r}
\hline \multicolumn{1}{c}{ Model } & \multicolumn{2}{c|}{$\begin{array}{c}\text { Coefficients } \\
\text { Unstandardized } \\
\text { Coefficients }\end{array}$} & $\begin{array}{l}\text { Standa. } \\
\text { Coeffici } \\
\text { ents }\end{array}$ & t & Sig. \\
& $\mathrm{B}$ & S. Error & Beta & & \\
\hline (Constant) & 4,188 &, 898 & & 4,665 &, 002 \\
\hline Hambatan Samping &, 004 &, 013 &, 622 &, 280 &, 787 \\
\hline Volume Lalulintas &, 001 &, 002 & 1,134 &, 581 &, 579 \\
\hline Tata Guna Lahan &,- 613 &, 166 &,- 826 & $-3,690$ &, 008 \\
\hline Aktifitas Ekonomi &,- 162 &, 061 & $-1,394$ & $-2,666$ &, 032 \\
\hline a. Dependent Variable: Pola Pergerakan & & & &
\end{tabular}

Berdasarkan tabel 21 jika nilai sig $<0,05$ atau $\mathrm{T}$ hitung $>\mathrm{T}$ tabel maka terdapat pengaruh variabel $\mathrm{X}$ terhadap variabel Y. Variabel X1 = 0,787 dan X2 = 0,579 lebih besar dari 0,05 artinya variabel Hambatan Samping dan Volume Lalulintas tidak berpengaruh secara signifikan terhadap Pola Pergerakan (Z). Adapun nilai sig. X3 = 0,008 dan $\mathrm{Y}=0,032<0,05$ maka dapat disimpulkan Kompleksitas Guna Lahan dan Aktifitas Ekonomi berpengaruh terhadap Pola Pergerakan (Z) Jalan Letnan Jendral Hertasning.

Nilai $\mathrm{T}$ tabel dapat dihitung dengan $\mathrm{df}=(\mathrm{n}-\mathrm{k}-1)=$ 2,306. Nilai $\mathrm{T}$ hitung $\mathrm{X} 1=0,280, \mathrm{X} 2=0,581, \mathrm{X} 3=-3,690$ dan $\mathrm{Y}=-2,666<\mathrm{T}$ tabel maka tidak terdapat pengaruh variabel secara parsial.

Dampak Urban Sprawl terhadap Pola Pergerakan Studi Pada Koridor Jalan Letjend Hertasning Kota Makassar bahwa kenampakan dari variabel yang diteliti serta besaran pengaruh dari Hambatan samping, Volume lalulintas, Kompleksitas Guna Lahan, Aktifitas Perdagangan dan Pola Pergerakan sebagai berikut :

1) Hambatan Samping

Hasil observasi menunjukkan bahwa indikator yang paling berpengaruh terhadap tingginya hambatan samping di Jl. Letjend Hertasning adalah kendaraan yang melambat sedangkan kendaraan masuk atau keluar merupakan kontribusi paling rendah terhadap variabel hambatan samping. Adapun waktu penelitian yang paling tinggi hambatan sampingnya adalah pada Hari Minggu (libur/akhir pekan) pada segmen IV Arah dari Jl. Letjend Hertasning ke Jl. Tun Abdul Razak.

2) Volume Lalulintas

Pada keempat segmen lokasi penelitian ini dapat Nampak bahwa Segmen IV pada ruas Jl. Letjend Hertasning berkontribusi sangat tinggi terhadap volume lalu lintas sebesar 50,93\% dan paling rendah adalah Segmen IB senilai 3,72\%.

3) Kompleksitas Guna Lahan

Kondisi segmen I pada ruas Jalan Letjend. Hertasning sangat kompleks dibandingka dengan segmen IV dimana hanya memilki 2 fungsi lahan dominan yakni permukiman dan perdagangan sesuai dengan penjabaran pada tabel 19

4) Aktifitas Perdagangan

Kondisi aktifitas perdaganag pada segmen I sangat rendah sedangkan pada segmen IV sangat tinggi. Dapat dilihat pada tabel 12 dengan ketidakseimbangan jumlah pedagang formal dan nonformal yang didonimasi oleh kegiatan perdagangan non formal

5) Pola Pergerakan

Berdasarkan tabel 13 disimpulkan bahwa pola pergerakan dominan pada 4 segmen yang diuji dalam 3 perbedaan waktu yakni

- Jalan Letjend. Hertasning sebagai jalur utama untuk bekerja.

- Jalan Letjend. Hertasning sebagai Tujuan atau asal perjalanan untuk melakukan kegiatan kerja

- Jalan Letjend Hertasning sebagai Tujuan atau asal untuk melakukan kegiatan ekonomi.

6) Pengaruh Hambatan samping, Volume lalulintas, Kompleksitas Guna Lahan, Aktifitas Perdagangan terhadap Pola Pergerakan 
Tabel 5 Hasil Penelitian Variabel X1 Hambatan Samping

\begin{tabular}{|c|c|c|c|c|c|c|c|c|c|c|c|}
\hline No & Segmen & $\begin{array}{c}\mathrm{N} \\
\text { Pejalan } \\
\text { kaki }\end{array}$ & $\begin{array}{l}\text { Total } \\
\text { PED }\end{array}$ & $\begin{array}{c}\mathrm{N} \\
\text { Kendaraan } \\
\text { berhenti }\end{array}$ & $\begin{array}{l}\text { Total } \\
\text { PSV }\end{array}$ & $\begin{array}{l}\text { N K. } \\
\text { masuk/ } \\
\text { keluar }\end{array}$ & $\begin{array}{l}\text { Total } \\
\text { EEV }\end{array}$ & $\begin{array}{c}\mathrm{N} \mathrm{K} . \\
\text { melambat }\end{array}$ & $\begin{array}{l}\text { Total } \\
\text { SMV }\end{array}$ & $\begin{array}{l}\text { Grand } \\
\text { Total }\end{array}$ & Kelas \\
\hline 1 & Segmen I A & 15 & 7,5 & 24 & 24 & 10 & 7 & 335,36 & 134 & 172,64 & Tinggi \\
\hline 2 & Segmen I B & 15 & 7,5 & 24 & 24 & 10 & 7 & 316,96 & 127 & 165,28 & Tinggi \\
\hline 3 & Segmen I C & 15 & 7,5 & 24 & 24 & 10 & 7 & 323,72 & 129 & 167,98 & Tinggi \\
\hline 4 & Segmen II A & 10 & 5 & 20 & 20 & 14 & 9,8 & 399,44 & 160 & 194,58 & Tinggi \\
\hline 5 & Segmen II B & 10 & 5 & 20 & 20 & 14 & 9,8 & 404,88 & 162 & 196,75 & Tinggi \\
\hline 6 & Segmen II C & 10 & 5 & 20 & 20 & 14 & 9,8 & 404,88 & 165 & 199,56 & Tinggi \\
\hline 7 & Segmen III A & 21 & 10,5 & 35 & 35 & 20 & 14 & 887,36 & 355 & 414,44 & Sangat Tinggi \\
\hline 8 & Segmen III B & 21 & 10,5 & 35 & 35 & 20 & 14 & 1003,92 & 402 & 461,07 & Sangat Tinggi \\
\hline 9 & Segmen III C & 21 & 10,5 & 35 & 35 & 20 & 14 & 1003,92 & 409 & 468,68 & Sangat Tinggi \\
\hline 10 & Segmen IV A & 36 & 18 & 35 & 35 & 29 & 20,3 & 1018,72 & 407 & 480,79 & Sangat Tinggi \\
\hline 11 & Segmen IV B & 36 & 18 & 35 & 35 & 29 & 20,3 & 1035,93 & 414 & 487,67 & Sangat Tinggi \\
\hline \multirow[t]{2}{*}{12} & Segmen IV C & 36 & 18 & 35 & 35 & 29 & 20,3 & 1062,56 & 425 & 498,32 & Sangat Tinggi \\
\hline & Total & 246 & & 342 & & 219 & & 8223,7 & 3289 & 3907,78 & \\
\hline
\end{tabular}

Sumber: Hasil Analisis, 2020

Tabel 6 Distribusi Frekuensi Variabel Hambatan Samping

\begin{tabular}{|c|c|c|c|c|c|c|c|c|c|c|c|c|}
\hline \multirow{2}{*}{ Item } & \multicolumn{2}{|c|}{ ST } & \multicolumn{2}{|c|}{$\mathrm{T}$} & \multicolumn{2}{|c|}{ CT } & \multicolumn{2}{|c|}{$\mathrm{R}$} & \multicolumn{2}{|c|}{ SR } & \multicolumn{2}{|c|}{ Total } \\
\hline & $\mathrm{F}$ & $\%$ & $\mathrm{~F}$ & $\%$ & $\mathrm{~F}$ & $\%$ & $\mathrm{~F}$ & $\%$ & $\mathrm{~F}$ & $\%$ & $\mathrm{~F}$ & $\%$ \\
\hline X1.1 & 171 & 69,5 & 75 & 30,5 & - & - & - & - & - & - & 246 & 100 \\
\hline X 1.2 & 210 & 61,4 & 132 & 38,6 & - & - & - & - & - & - & 342 & 100 \\
\hline$X 1.3$ & 147 & 67,1 & 72 & 32,9 & - & - & - & - & - & - & 219 & 100 \\
\hline X 1.4 & 6031 & 73 & 2192 & 27 & - & - & - & - & - & - & 8224 & 100 \\
\hline
\end{tabular}

Sumber: Hasil Analisis, 2020

Tabel 7 Hasil Penelitian Variabel X2 Volume Lalulintas

\begin{tabular}{|c|c|c|c|c|c|c|c|c|c|c|}
\hline No & Segmen & $\begin{array}{c}\text { Co } \\
\text { (smp/jam) }\end{array}$ & $\mathrm{FCw}$ & FCsp & $\mathrm{FCsf}$ & FCCs & Kapasitas Jalan & $\mathrm{Q}$ (Arus) & DS & Kelas \\
\hline 1 & Segmen I A & 3300 & 1,08 & 1 & 0,92 & 1 & 3278,88 & 838,40 & 0,26 & Rendah \\
\hline 2 & Segmen I B & 3300 & 1,08 & 1 & 0,92 & 1 & 3278,88 & 792,40 & 0,24 & Sangat Rendah \\
\hline 3 & Segmen I C & 3300 & 1,08 & 1 & 0,92 & 1 & 3278,88 & 809,30 & 0,25 & Rendah \\
\hline 4 & Segmen II A & 3300 & 1,08 & 1 & 0,92 & 1 & 3278,88 & 998,60 & 0,30 & Rendah \\
\hline 5 & Segmen II B & 3300 & 1,08 & 1 & 0,92 & 1 & 3278,88 & $1.012,20$ & 0,31 & Rendah \\
\hline 6 & Segmen II C & 3300 & 1,08 & 1 & 0,92 & 1 & 3278,88 & $1.029,75$ & 0,31 & Rendah \\
\hline 8 & Segmen III B & 3300 & 1,08 & 1 & 0,88 & 1 & 3136,32 & $2.509,80$ & 0,80 & Tinggi \\
\hline 9 & Segmen III C & 3300 & 1,08 & 1 & 0,88 & 1 & 3136,32 & $2.557,40$ & 0,82 & Sangat Tinggi \\
\hline 10 & Segmen IV A & 3300 & 1,08 & 1 & 0,88 & 1 & 3136,32 & $2.546,80$ & 0,81 & Sangat Tinggi \\
\hline 11 & Segmen IV B & 3300 & 1,08 & 1 & 0,88 & 1 & 3136,32 & $2.656,40$ & 0,85 & Sangat Tinggi \\
\hline 12 & Segmen IV C & 3300 & 1,08 & 1 & 0,88 & 1 & 3136,32 & $2.589,80$ & 0,83 & Sangat Tinggi \\
\hline
\end{tabular}

Tabel 8 Distribusi Frekuensi Variabel Volume Lalulintas

\begin{tabular}{|c|c|c|c|c|c|c|c|c|c|c|c|c|}
\hline \multirow{2}{*}{ Item } & \multicolumn{2}{|c|}{ ST } & \multicolumn{2}{|c|}{$\mathrm{T}$} & \multicolumn{2}{|c|}{$\mathrm{CT}$} & \multicolumn{2}{|c|}{$\mathrm{R}$} & \multicolumn{2}{|c|}{ SR } & \multicolumn{2}{|c|}{ Total } \\
\hline & $\mathrm{F}$ & $\%$ & $\mathrm{~F}$ & $\%$ & $\mathrm{~F}$ & $\%$ & $\mathrm{~F}$ & $\%$ & $\mathrm{~F}$ & $\%$ & $\mathrm{~F}$ & $\%$ \\
\hline $\mathrm{X} 2$ & 3,30 & 50,93 & 1,51 & 23,3 & - & - & 1,43 & 22,07 & 0,24 & 3,72 & 6,48 & 100 \\
\hline
\end{tabular}

Sumber: Hasil Analisis, 2020

Tabel 9 Kompleksitas Guna Lahan

\begin{tabular}{|c|c|c|c|c|c|c|c|c|}
\hline No & Segmen & $\mathbf{N} \mathbf{X} 3$ & & & Keterangan & & & Kelas \\
\hline 1 & Segmen I A & 5 & Perdagangan & Perkantoran & Permukiman & Sekolah & Peribadatan & Sangat Kompleks \\
\hline 2 & Segmen I B & 5 & Perdagangan & Perkantoran & Permukiman & Sekolah & Peribadatan & Sangat Kompleks \\
\hline 3 & Segmen I C & 5 & Perdagangan & Perkantoran & Permukiman & Sekolah & Peribadatan & Sangat Kompleks \\
\hline 4 & Segmen II A & 3 & Permukiman & Perdagangan & Kesehatan & & & Cukup Kompleks \\
\hline 5 & Segmen II B & 3 & Permukiman & Perdagangan & Kesehatan & & & Cukup Kompleks \\
\hline 6 & Segmen II C & 3 & Permukiman & Perdagangan & Kesehatan & & & Cukup Kompleks \\
\hline 7 & Segmen III A & 4 & Permukiman & Perdagangan & Sekolah & Peribadatan & & Kompleks \\
\hline 8 & Segmen III B & 4 & Permukiman & Perdagangan & Sekolah & Peribadatan & & Kompleks \\
\hline 9 & Segmen III C & 4 & Permukiman & Perdagangan & Sekolah & Peribadatan & & Kompleks \\
\hline 10 & Segmen IV A & 2 & Permukiman & Perdagangan & & & & Kurang Kompleks \\
\hline 11 & Segmen IV B & 2 & Permukiman & Perdagangan & & & & Kurang Kompleks \\
\hline 12 & Segmen IV C & 2 & Permukiman & Perdagangan & & & & Kurang Kompleks \\
\hline
\end{tabular}


Tabel 10 Distribusi Frekuensi Variabel Kompleksitas Guna Lahan

\begin{tabular}{|c|c|c|c|c|c|c|c|c|c|c|c|c|}
\hline \multirow{2}{*}{ Item } & \multicolumn{2}{|c|}{ SK } & \multicolumn{2}{|c|}{$\mathrm{K}$} & \multicolumn{2}{|c|}{ KK } & \multicolumn{2}{|c|}{ CK } & \multicolumn{2}{|c|}{$\mathrm{S}$} & \multicolumn{2}{|c|}{ Total } \\
\hline & $\mathrm{F}$ & $\%$ & $F$ & $\%$ & $\mathrm{~F}$ & $\%$ & $F$ & $\%$ & $\mathrm{~F}$ & $\%$ & $\mathrm{~F}$ & $\%$ \\
\hline X3 & 3 & 25 & 3 & 25 & 3 & 25 & 3 & 25 & - & - & 12 & 100 \\
\hline
\end{tabular}

Sumber: Hasil Analisis, 2020

Tabel 11 Distribusi Frekuensi Variabel Aktifitas Perdagangan

\begin{tabular}{|c|c|c|c|c|c|c|c|c|c|c|c|c|}
\hline & \multirow{2}{*}{ Item } & \multicolumn{2}{|c|}{ ST } & \multicolumn{2}{|r|}{$\mathrm{T}$} & \multicolumn{2}{|r|}{ CT } & \multicolumn{2}{|c|}{$\mathrm{R}$} & SR & \multicolumn{2}{|c|}{ Total } \\
\hline & & $\bar{F}$ & $\%$ & $\bar{F}$ & $\%$ & $\bar{F}$ & $\%$ & $F$ & $\%$ & $\%$ & $\bar{F}$ & $\%$ \\
\hline Y & & 3 & $25 \%$ & 3 & $25 \%$ & 3 & $25 \%$ & 3 & $25 \%$ & - & 12 & 100 \\
\hline \multicolumn{13}{|c|}{ Sumber: Hasil Analisis, 2020} \\
\hline No & & \multicolumn{2}{|c|}{ Segmen } & \multicolumn{2}{|r|}{ Formal } & \multicolumn{3}{|c|}{ Non Formal } & Total & \multicolumn{3}{|c|}{ Kelas } \\
\hline 1 & \multicolumn{3}{|c|}{ Segmen I A } & \multicolumn{2}{|r|}{4} & \multicolumn{3}{|c|}{6} & 10 & \multicolumn{3}{|c|}{ Sangat Rendah } \\
\hline 2 & \multicolumn{3}{|c|}{ Segmen I B } & \multicolumn{2}{|r|}{4} & \multicolumn{3}{|c|}{6} & 10 & \multicolumn{3}{|c|}{ Sangat Rendah } \\
\hline 3 & \multicolumn{3}{|c|}{ Segmen I C } & \multicolumn{2}{|r|}{4} & \multicolumn{3}{|c|}{6} & 10 & \multicolumn{3}{|c|}{ Sangat Rendah } \\
\hline 4 & \multicolumn{3}{|c|}{ Segmen II A } & \multicolumn{2}{|r|}{8} & \multicolumn{3}{|c|}{6} & 14 & \multicolumn{3}{|l|}{ Rendah } \\
\hline 5 & \multicolumn{3}{|c|}{ Segmen II B } & \multicolumn{2}{|r|}{8} & \multicolumn{3}{|c|}{6} & 14 & \multicolumn{3}{|l|}{ Rendah } \\
\hline 6 & \multicolumn{3}{|c|}{ Segmen II C } & & 8 & & 6 & & 14 & Rendah & & \\
\hline 7 & Segm & & & & 8 & & 12 & & 20 & Cukup Tin & & \\
\hline 8 & Segm & & & & 8 & & 12 & & 20 & Cukup Tin & & \\
\hline 9 & Segm & & & & 8 & & 12 & & 20 & Cukup Tin & & \\
\hline 10 & Segm & & & & 9 & & 20 & & 29 & Sangat Tin & & \\
\hline 11 & Segm & & & & 9 & & 20 & & 29 & Sangat Tin & & \\
\hline 12 & Segm & & & & 9 & & 20 & & 29 & Sangat Tin & & \\
\hline & Total & & & & & & & & & & & \\
\hline
\end{tabular}

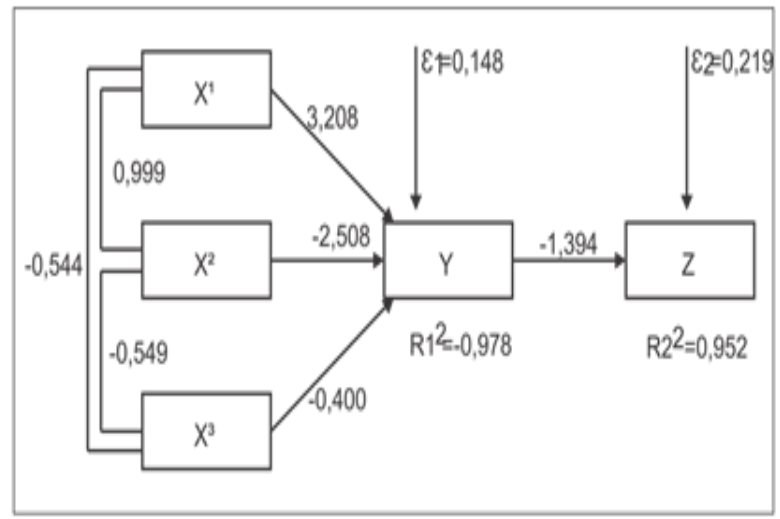

$X 1=$ Hambatan Samping

$\mathrm{X} 2=$ Volume Lalulintas

X3 = Kompleksitas Guna Lahan

$Y=$ Aktifitas Ekonomi

$Z$ = Pola Pergerakan

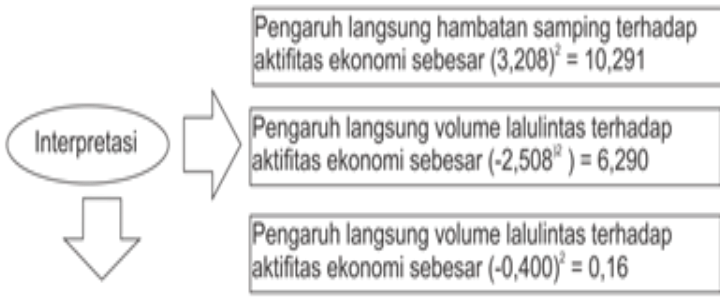

Hubungan atau korelasi antara variabel Hambatan samping dengan variabel Volume lalulintas sebesar 0,999

Hubungan atau korelasi antara variabel Hambatan samping dengan variabel kompleksitas guna lahan sebesar $-0,544$

Hubungan atau korelasi antara Volume lalulintas dengan variabel kompleksitas guna lahan sebesar $-0,549$ 


\section{Kesimpulan dan Saran}

Hasil penelitian dapat disimpulkan bahwa indikator yang paling mempengaruhi terhadap variabel Hambatan Samping pada ruas Jalan Letnan Jenderal Hertasning adalah kendaraan yang melambat sedangkan kendaraan masuk atau keluar merupakan kontribusi paling rendah. Adapun keadaan hambatan samping tertinggi terjadi pada waktu akhir pekan (Hari Minggu) pada segmen IV Arah dari Jl. Letjend Hertasning ke Jl. Tun Abdul Razak. Diantara keempat segmen lokasi penelitian Jalan Letnan Jenderal pada Segmen IV berkontribusi sangat tinggi terhadap volume lalu lintas sebesar $50,93 \%$ terhadap volume lalulintas kendaraan dengan kondisi Derajat kejenuhan lebih dari 0,81 dengan kategori kelas sangat tinggi. Kompleksitas guna lahan berbeda-beda di tiap segmen lokasi penelitian ruas Jalan Letnan Jenderal Hertasning dengan fungsi Permukiman, Perdagangan, Perkantoran, Sekolah, hingga Peribadatan dengan tingkat sederhana hingga kompleks. Adapun segmen I memiliki guna lahan yang sangat kompleks dan segmen IV yang paling sederhana.

\section{Daftar Pustaka}

Almeida, B. (2005). A GIS Assessment of Urban Sprawl in Richmond, Virginia. Blacksburg. Virginia Polytechnic Institute and State University.

Bintarto, R. (1983). Interkasi Kota - Desa dan Permasalahannya. Yogyakarta: Ghalia Indonesia.

Departemen Pekerjaan Umum., 1997, Manual Kapasitas Jalan Indonesia (MKJI), Direktorat Jenderal Bina Marga dan Departemen Pekerjaan Umum Jakarta.

Karakayaci, Z. (2017). The concept of urban sprawl and its causes. The Journal of International Social Research, 9(45), 815-818. doi:10.17719/jisr.20164520658.

Mahmud, A., \& Achide, A. S. (2012). Analysis of land use/land cover changes to monitor urban sprawl in keffinigeria. Environmental Research Journal, 6(2), 130-135.

Nasaruddin, M. M., Manaf, M., \& Saleh, H. (2020). Pengaruh Pengembangan Kawasan Perumahan Terhadap Sosial Ekonomi dan Minimalisasi Gejala Urban Sprawl. Urban and Regional Studies Journal, 2(1), 15-24.

Slaev, Aleksandar, D., \& Nikiforov, I. (2013). Factors of urban sprawl in Bulgaria. SPATIUM International Review, 29, 22-29.

Soetomo, S. (2013). Urbanisasi dan Morfologi, Proses perkembangan peradaban \& wadah ruang: Menuju ruang kehidupan yang manusiawi. Yogyakarta: Graha Ilmu.

Sudhira, H. ., \& Ramachandra, T. . (2007). Characterising urban sprawl from remote sensing data and using landscape metrics. In 10th International Conference on Computers in Urban Planning and Urban Management. Brazil: Iguassu Falls.
Yunus, H. S. (2008). Dinamika Wilayah Peri Urban Determinan Masa Depan Kota. Yogyakarta: Pusataka Pelajar 